\title{
Varicella Zoster Virus Screening
}

National Cancer Institute

\section{Source}

National Cancer Institute. Varicella Zoster Virus Screening. NCI Thesaurus. Code C92916.

A test to determine if an individual has antibodies to the varicella zoster virus. 